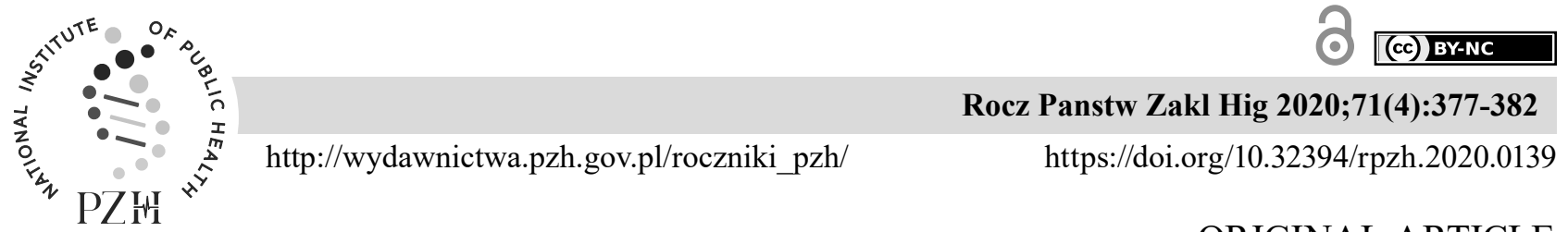

ORIGINAL ARTICLE

\title{
RADIATION MONITORING OF AGRICULTURAL SOILS OF THE VOLYN REGION IN UKRAINE
}

\author{
Oksana Hromyk ${ }^{1}$, Leonid Ilyin ${ }^{2}$, Igor Grygus ${ }^{3}$,Serhii Korotun ${ }^{3}$, Olga Ilyina ${ }^{2}$, Walery Zukow \\ ${ }^{1}$ Lutsk Technical National University, Lvivska 75, 43018, Lutsk, Ukraine \\ ${ }^{2}$ Lesia Ukrainka Eastern European National University, Volia Avenue»13, 43025, Lutsk, Ukraine \\ ${ }^{3}$ National University of Water and Environmental Engineering, Soborna 11, 33028, Rivne, Ukraine \\ ${ }^{4}$ Nicolaus Copernicus University, Gagarina 11 str., 87-100 Toruń, Poland
}

\begin{abstract}
Background. The development of effective environmental management programs requires an appropriate assessment of the current state of the environment and contributes to anticipating future changes in the state of the environment. Obtaining such information is one of the main objectives of monitoring the environment, which is subject to anthropogenic stress, including radiological contamination. The distribution of radionuclides and their ability to migrate in ecological chains and concentration in individual parts requires special control in contaminated areas.

Objective. The purpose of the study was to analyze the content of radionuclides $\left({ }^{137} \mathrm{Cs}\right.$ and $\left.{ }^{90} \mathrm{Sr}\right)$ in soils near the settlements of the zone of radioactive contamination of the Volyn region and their spatial differentiation. Priority is given to agricultural lands, soils, crop products, which necessitates the organization of targeted monitoring of the agro industrial complex

Material and methods. Radioactivity from ${ }^{137} \mathrm{Cs}$ and ${ }^{90} \mathrm{Sr}$ in the soil originating in the Volyn region was studied from 1996 to 2018. Radiation control was carried out on the area of 59852 ha (arable land - 38897 ha, meadows and pastures 20955 ha).

Results. A significant part of the study area has elevated levels of radioactive contamination. The density of radionuclide contamination of agricultural soils in the settlements of the region has been determined. Density of pollution of all surveyed agricultural lands ${ }^{137} \mathrm{Cs}$ ranges from 0.01 to $2.826 \mathrm{Ci} / \mathrm{km}^{2}$, and ${ }^{90} \mathrm{Sr}$ from 0.01 to $0.048 \mathrm{Ci} / \mathrm{km}^{2}$.

Conclusions. The radiological situation in the Volyn region (Ukraine) remains stable. There are slight fluctuations of ${ }^{137} \mathrm{Cs}$ and ${ }^{90} \mathrm{Sr}$, which is due to changes in weather conditions, which leads to an increase or decrease in groundwater and as a consequence - the migration of radionuclides. The most polluted were the soils of administrative districts of Manevychi and Liubeshiv.
\end{abstract}

Key words: radionuclides, ${ }^{90} \mathrm{SR},{ }^{137} \mathrm{CS}$, radioactive contamination, soils, monitoring, settlement

\section{INTRODUCTION}

Rational use of agricultural lands in the conditions of technogenic impact on the environment, in particular optimization of nature use in the zone of radioactive contamination is an important task of modern times [13]. One of the most important objects of radiation pollution monitoring is the sphere of agricultural production, especially crop and livestock products. The main source of radionuclides in human food is soil. Radionuclides are absorbed by plants and entered the crop products, and during its use they are absorbed in the human body.

Taking into consideration the behavior of radionuclides in the natural environment and decisionmaking on measures to reduce radioecological indicators of risks caused by the Chernobyl disaster remain relevant. The Volyn region, in particular the Kamin-Kashyrsky, Lyubeshivskyi and Manevychi administrative districts, also suffered from radioactive contamination. Much of the territory of these areas has elevated levels of radioactive contamination. To solve the problems related to the optimization of agro-landscapes in the conditions of radioactive contamination requires a comprehensive analysis of the ecostates of the study area.

The analysis of stock materials on the contaminated territories of the Volyn region showed the absence of scientific generalizations on radioactive contamination formed on the basis of unified approaches. The available information needs to be overviewed and systematized. It is necessary for the development of these conclusions, proposals for the rational use of agricultural land has been 
exposed to radioactive contamination. The content of radionuclides, ecostate of landscapes of the region, the degree of safety of local water and resources use were studied periodically. Many years of research, considerable attention has been paid to the use of water, biotic and land resources. However, there is an urgent need to clarify the state, dynamics, spatial distribution of radiation pollution, which largely determines the environmental safety of residents.

This problem of contamination of toxic substances is devoted a significant amount of studies. Special attention is paid to works by Samoilenko who proposed a comprehensive zoning of radioactive contaminated areas and the possible ecological consequences of the resource [16], Tavrov [17] who identified the most environmentally hazardous local complexes and forms of the use of water, biological and land resources of geosystems reservoirs of the Polessia and North Forest. Ilyina et al. [8, 9, 10, 11] have studied natural ponds as the environment complexes and accumulation of sediments and established geochemical indicators of the conditions investigated anthropogenic transformation processes and the sources and types of toxic substances in the conditions of Ukrainian Polissia. Korotun [12] analysed the monitoring of radiation pollution in the territory of Rivne region, Romanchuk [15] carried out the evaluation of the radioecological formation of radiation doses to rural residents of Polissia of Ukraine, Hromyk et al. [4, 5, 6, 7] have carried out eco-geographical substantiation of optimisation of agricultural landscapes in the zone of radioactive contamination of the Volyn region, Dutov [1] has considered agroecological aspects of minimize population exposure and Grygus et al. [3] found out the medical and geographical aspects of radioactive contamination. However, important special and temporal aspects of the propagation and accumulation of pollutants especially near settlements require detailed studies. It is part of a wide system of measures on liquidation of consequences of Chernobyl accident.

The purpose of the study was to analyse the content of radionuclides in soils near the settlements of the zone of radioactive contamination of the Volyn region and their spatial differentiation.

\section{STUDY AREA}

Radiation control was carried out on an area of 59852 ha (arable land - 38897 ha, meadows and pastures - $20955 \mathrm{ha}$ ) in seven administrative districts of the Volyn region (Ukraine), including in the area of radioactive contamination (Manevychi, Lyubeshiv and Kamin-Kashyrskyi administrative districts).

\section{MATERIALS AND METHODS}

To assess the effects of pollution, data on surface contamination of soils with radionuclides ${ }^{137} \mathrm{Cs}$ and ${ }^{90} \mathrm{Sr}\left(\mathrm{Ci} / \mathrm{km}^{2}\right)$ were used. All measurements were carried out in the Laboratory of Ecological Land Safety and Product Quality of the Volyn Branch of the State Institution 'Soil Protection Institute of Ukraine' (Lutsk). Determination of ${ }^{137} \mathrm{Cs}$ in soil was performed by the gamma-spectrum method on the AI-1024-95-17 unit, as well as on the PSA 68-01, RUB-01P6 radiometers, SEG-02, SEG-05 gamma spectrometers. The results of internal control over the accuracy of gamma spectrometric work to determine ${ }^{137} \mathrm{Cs}$ showed that the main relative error of measurements does not exceed $7 \%$, of the allowable $25 \% .{ }^{90} \mathrm{Sr}$ was determined by a radiochemical method with measurement on a modernized DP-100 No A 16878 installation with PSO 3-4 M 09 [14].

The main types of soils are sod-podzolic, podzolic, chernozem, sod and swamp. The area of radioactive contamination of the region is characterized by a high rate of transfer of radionuclides from the soil to plants, which complicates the radiation situation and can adversely affect the health of residents [16].

\section{RESULTS AND DISCUSSION}

As a result of the Chernobyl catastrophe, radionuclides that went outside the station were released into the atmosphere, where they accumulated. High migration capacity in the food chain (soil $\rightarrow$ plant $\rightarrow$ animal $\rightarrow$ livestock products) led to their entry into the human body. Internal radiation was added to the external irradiation. The presence of long-lasting radionuclides in the food chain causes internal exposure of humans and animals for many decades after contamination. Radionuclides get into the environment in different ways, but the soil, due to its absorbency, is the main accumulator of radioactive isotopes.

The ability to migrate and concentrate in certain parts of the food chain necessitated the organization of targeted monitoring of the agro-industrial complex. The monitoring system includes: observation and assessment of the level of radioactive contamination of nature components and biota elements in order to prevent possible negative consequences for human health; identification of patterns of spatial and temporal migration of radionuclides in biotic chains and making a forecast on this basis of future levels of radioactive contamination.

The purpose of radiation pollution monitoring is to accumulate the information needed to make decisions on the management and regulation of radioactive contamination of the natural environment 
and to develop measures to reduce the absorption of doses by the population. Taking into account specific tasks and purposes, monitoring programs are developed, which establish the choice of objects of observation, type, frequency and frequency of changes, sampling, their further laboratory analysis, methods of statistical processing of results, principles of collection, accumulation and processing of information.

The only source of objective information about the radiation situation is direct observations and measurements. Monitoring of radiation pollution includes: periodic measurements of dose rates of $\beta$ and $\gamma$ parts in the field; periodic sampling at specially selected observation sites and control points, determination of the concentration of radionuclides in these samples, radiation contamination and physicochemical forms of radionuclides; calculation of dose loads on biota on the basis of primary data of radiation pollution monitoring; assessment of current conditions and forecasting of possible changes in the radiation situation.

Several authors $[8,16,17]$ have studied the radioactivity of soils and other elements of the environment in Ukraine after the Chernobyl disaster, drawing attention to the identification of the most heavily contaminated sites and to the ecological consequences.

According to the results of monitoring (1994-1995) of ${ }^{137} \mathrm{Cs}$ and ${ }^{90} \mathrm{Sr}$ soil contamination in settlements, it

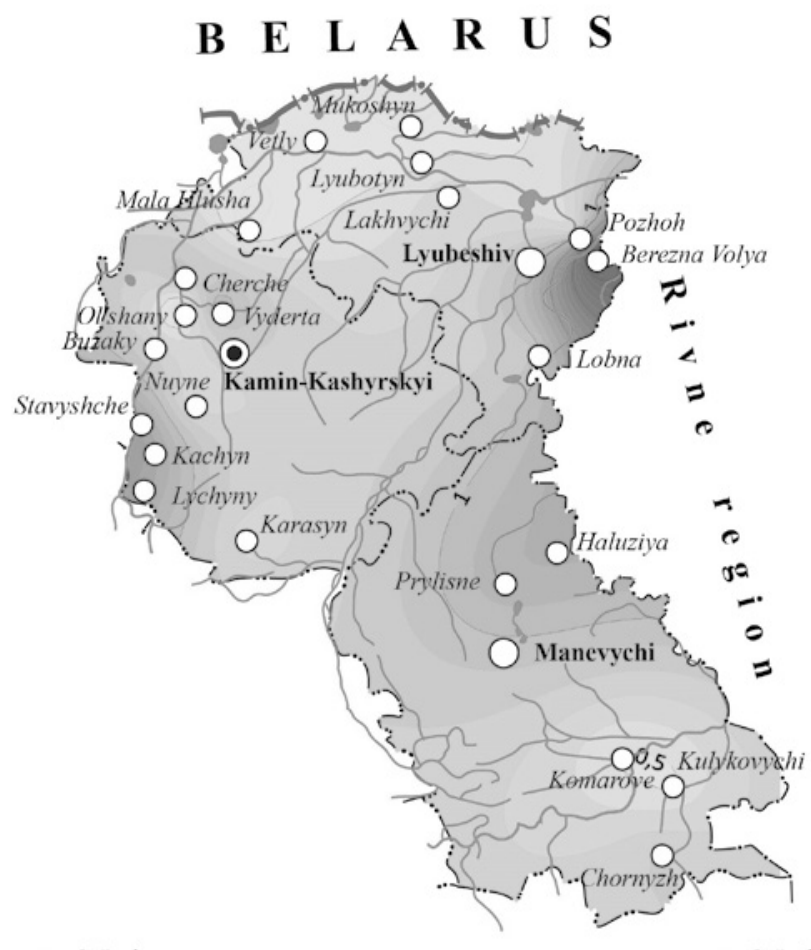

$0.24 \mathrm{Ci} / \mathrm{km}^{2}$

$2.8 \mathrm{Ci} / \mathrm{km}^{2}$

Figure 1. Distribution of radionuclide ${ }^{137} \mathrm{Cs}$ content in soils (according to observation points, 1994-1995), Ci $/ \mathrm{km}^{2}$ was established that the maximum content of ${ }^{137} \mathrm{Cs}$ and ${ }^{90} \mathrm{Sr}$ is available in the Lyubeshiv administrative district of the village Berezna Volya $\left({ }^{137} \mathrm{Cs}-2.83 \mathrm{Ci} /\right.$ $\left.\mathrm{km}^{2},{ }^{90} \mathrm{Sr}-0.04 \mathrm{Ci} / \mathrm{km}^{2}\right)$ and village Lakhvychi $\left({ }^{137} \mathrm{Cs}-\right.$ $0.65 \mathrm{Ci} / \mathrm{km}^{2},{ }^{90} \mathrm{Sr}-0.04 \mathrm{Ci} / \mathrm{km}^{2}$ ) (Table 1, Figure 1).

According to the level of soil contamination of the territory, settlements with villsges Lychyny, Stavyshche, Kachin (Kamin-Kashyrskiy district), Berezna Volia (Lyubeshiv district), Haluziya, Prylisne (Manevychi district) we attributed to the zone of enhanced radiation control (Table 2).

Table 1. Results on complex monitoring of radiation pollution of soils in the settlements of Kamin-Kashirskyi, Lyubeshivskyi and Manevychi areas of the Volyn region, Ukraine (1994-1995)

\begin{tabular}{|c|c|c|c|}
\hline No & Settlement & $\begin{array}{c}{ }^{137} \mathrm{Cs} \\
\mathrm{Ci} / \mathrm{km}^{2}\end{array}$ & $\begin{array}{c}{ }^{90} \mathrm{Sr} \\
\mathrm{Ci} / \mathrm{km}^{2}\end{array}$ \\
\hline \multicolumn{4}{|c|}{ Kamin-Kashira district } \\
\hline \multicolumn{4}{|c|}{1994} \\
\hline 1 & Lychyny & 1.398 & 0.028 \\
\hline 2 & Buzaky & 0.794 & 0.026 \\
\hline 3 & Cherche & 0.968 & 0.022 \\
\hline 4 & Stavyshche & 1.404 & 0.014 \\
\hline 5 & Nuyne & 0.614 & 0.024 \\
\hline \multicolumn{4}{|c|}{1995} \\
\hline 1 & Karasin & 0.656 & 0.048 \\
\hline 2 & Viderta & 1.114 & 0.038 \\
\hline 3 & Kachin & 1.410 & 0.042 \\
\hline 4 & Olshani & 0.244 & 0.022 \\
\hline \multicolumn{4}{|c|}{ Lyubeshiv district } \\
\hline \multicolumn{4}{|c|}{1994} \\
\hline 1 & Mala Hlusha & 0.344 & 0.032 \\
\hline 2 & Mukoshyn & 0.384 & 0.026 \\
\hline 3 & Lakhvychi & 0.652 & 0.040 \\
\hline 4 & Berezna Volya & 2.826 & 0.040 \\
\hline \multicolumn{4}{|c|}{1995} \\
\hline 1 & Lobna & 0.868 & 0.028 \\
\hline 2 & Lyubotyn & 0.44 & 0.042 \\
\hline 3 & Vetly & 0.464 & 0.024 \\
\hline 4 & Pozhoh & 0.612 & 0.034 \\
\hline \multicolumn{4}{|c|}{ Manevychi district } \\
\hline \multicolumn{4}{|c|}{1994} \\
\hline 1 & Haluziya & 1.236 & 0.038 \\
\hline 2 & Kulykovychi & 0.466 & 0.012 \\
\hline 3 & Chornyzh & 0.810 & 0.024 \\
\hline \multicolumn{4}{|c|}{1995} \\
\hline 1 & Haluziya & 1.368 & 0.032 \\
\hline 2 & Komarove & 0.486 & 0.024 \\
\hline 3 & Prylisne & 1.182 & 0.030 \\
\hline
\end{tabular}

$1 \mathrm{Ci} / \mathrm{km}^{2}=37 \mathrm{kBq} / \mathrm{m}^{2}$ 
The results of radioecological monitoring of soils conducted in 1996-1998 in Kamin-Kashirsky, Lyubeshivsky and Manevychi districts are summarized in Table 3. Analysis of the results of the study of ${ }^{137} \mathrm{Cs}$ content in soils showed that the maximum content of radionuclides was recorded in 1997 in the village. Borovno $\left(0.27 \mathrm{Ci} / \mathrm{km}^{2}\right)$ Kamin-

Table 2. Scale for assessing the level of radioactive soil contamination ${ }^{137} \mathrm{Cs}$

\begin{tabular}{|c|c|c|}
\hline $\begin{array}{c}\text { Contamination } \\
\text { of the territory, } \\
\mathrm{Ci} / \mathrm{km}^{2}\end{array}$ & $\begin{array}{c}\text { Soil } \\
\text { contamination }\end{array}$ & $\begin{array}{c}\text { Possibility of } \\
\text { human habitation }\end{array}$ \\
\hline $0-1$ & Clean soil & $\begin{array}{c}\text { Ordinary } \\
\text { residence }\end{array}$ \\
\hline $1-5$ & $\begin{array}{c}\text { Zone of enhanced } \\
\text { radiation control }\end{array}$ & $\begin{array}{c}\text { Accommodation } \\
\text { is allowed }\end{array}$ \\
\hline $5-15$ & Contaminated soil & $\begin{array}{c}\text { Zone guaranteed } \\
\text { voluntary } \\
\text { resettlement }\end{array}$ \\
\hline
\end{tabular}

Table 3. Results on the complex monitoring of radiation pollution of soils in the settlements of Kamin-Kashirskyi, Lyubeshivskyi and Manevychi areas of the Volyn region, Ukraine (1996-1998)

\begin{tabular}{|c|c|c|c|c|}
\hline No & Settlement & $\begin{array}{l}\text { Year of } \\
\text { research }\end{array}$ & $\begin{array}{c}{ }^{137} \mathrm{Cs} \\
\mathrm{Ci} / \mathrm{km}^{2}\end{array}$ & $\begin{array}{c}{ }^{90} \mathrm{Sr} \\
\mathrm{Ci} / \mathrm{km}^{2}\end{array}$ \\
\hline \multicolumn{5}{|c|}{ Kamin-Kashirskiy district } \\
\hline \multirow{3}{*}{1} & \multirow{3}{*}{ Rakiv Lis } & 1996 & 0.12 & 0.01 \\
\hline & & 1997 & 0.15 & 0.02 \\
\hline & & 1998 & 0.06 & 0.02 \\
\hline \multirow{3}{*}{2} & \multirow{3}{*}{ Borovno } & 1996 & 0.25 & 0.01 \\
\hline & & 1997 & 0.27 & 0.02 \\
\hline & & 1998 & 0.18 & 0.01 \\
\hline \multicolumn{5}{|c|}{ Lyubeshiv district } \\
\hline \multirow{3}{*}{1} & \multirow{3}{*}{ Velyka Hlusha } & 1996 & 0.236 & 0.02 \\
\hline & & 1997 & 0.25 & 0.01 \\
\hline & & 1998 & 0.40 & 0.01 \\
\hline \multirow{3}{*}{2} & \multirow{3}{*}{$\begin{array}{c}\text { Volya } \\
\text { Lyubeshivska }\end{array}$} & 1996 & 0.20 & 0.03 \\
\hline & & 1997 & 0.34 & 0.01 \\
\hline & & 1998 & 0.23 & 0.01 \\
\hline \multicolumn{5}{|c|}{ Manevychi district } \\
\hline \multirow{3}{*}{1} & \multirow{3}{*}{ Lyshnivka } & 1996 & 0.34 & 0.03 \\
\hline & & 1997 & 0.41 & 0.02 \\
\hline & & 1998 & 0.27 & 0.02 \\
\hline \multirow{3}{*}{2} & \multirow{3}{*}{ Yablunka } & 1996 & 0.30 & 0.02 \\
\hline & & 1997 & 0.46 & 0.01 \\
\hline & & 1998 & 0.36 & 0.01 \\
\hline \multirow{3}{*}{3} & \multirow{3}{*}{ Komarovo } & 1996 & 0.14 & 0.01 \\
\hline & & 1997 & 0.26 & 0.01 \\
\hline & & 1998 & 0.17 & 0,03 \\
\hline
\end{tabular}

$1 \mathrm{Ci} / \mathrm{km}^{2}=37 \mathrm{kBq} / \mathrm{m}^{2}$
Kashirskiy district, village Volya Lyubeshivska $\left(0.34 \mathrm{Ci} / \mathrm{km}^{2}\right)$ of Lyubeshiv district and village Yablunka $\left(0.46 \mathrm{Ci} / \mathrm{km}^{2}\right)$ of Manevychi districts. The main ${ }^{90} \mathrm{Sr}$ batteries were soils in 1997 Rakiv Lis $\left(0.02 \mathrm{Ci} / \mathrm{km}^{2}\right)$ and village Borovno $\left(0.02 \mathrm{Ci} / \mathrm{km}^{2}\right)$ of Kamin-Kashirsky district. The maximum content of radionuclides in the soils of Lyubeshiv district is concentrated in the village Volia Lyubeshivska $(0.03$ $\left.\mathrm{Ci} / \mathrm{km}^{2}\right)$ in 1996 . The soils of the village Lyshnivka $\left(0.03 \mathrm{Ci} / \mathrm{km}^{2}\right)$ in 1996 and the village Komarovo $(0.03$ $\left.\mathrm{Ci} / \mathrm{km}^{2}\right)$ in 1998 , Manevychi district.

In 2011-2018, radiological control was carried out in seven administrative districts (Lyuboml, Shatsk, Starovyzhiv, Ratniv, Kivertsiv, Manevychi and Lutsk). The content of radionuclides was controlled on the area of 59852 ha (arable land - 38897 ha, meadows and pastures - $20955 \mathrm{ha}$ ). The density of contamination of the surveyed agricultural soils at ${ }^{137} \mathrm{Cs}$ was up to $1 \mathrm{Ci}$ / $\mathrm{km}^{2}$, and at ${ }^{90} \mathrm{Sr}$ up to $0.02 \mathrm{Ci} / \mathrm{km}^{2}$.

The highest indicators of density of ${ }^{137} \mathrm{Cs}$ contamination of soils are in the areas included in the zone of radioactive contamination, village Yablunka - $0.15 \mathrm{Ci} / \mathrm{km}^{2}$, village Kostyukhnivka - $0.24 \mathrm{Ci} / \mathrm{km}^{2}$, village Lyshnivka - $0.31 \mathrm{Ci} / \mathrm{km}^{2}$, village Prilisne $0.27 \mathrm{Ci} / \mathrm{km}^{2}$, village Sytnytsia $-0.09 \mathrm{Ci} / \mathrm{km}^{2}$, village Komarovo - $0.08 \mathrm{Ci} / \mathrm{km}^{2}$ Manevychi district; with. village Seat - $0.18 \mathrm{Ci} / \mathrm{km}^{2}$, village Velyka Hlusha - $0.11 \mathrm{Ci} / \mathrm{km}^{2}$, village Volya Lyubeshivska - 0.12 $\mathrm{Ci} / \mathrm{km}^{2}$ Lyubeshiv district (Table 4, Figure 2). According to toxicological indicators the soils of the experimental plots do not exceed the maximum allowable concentrations.

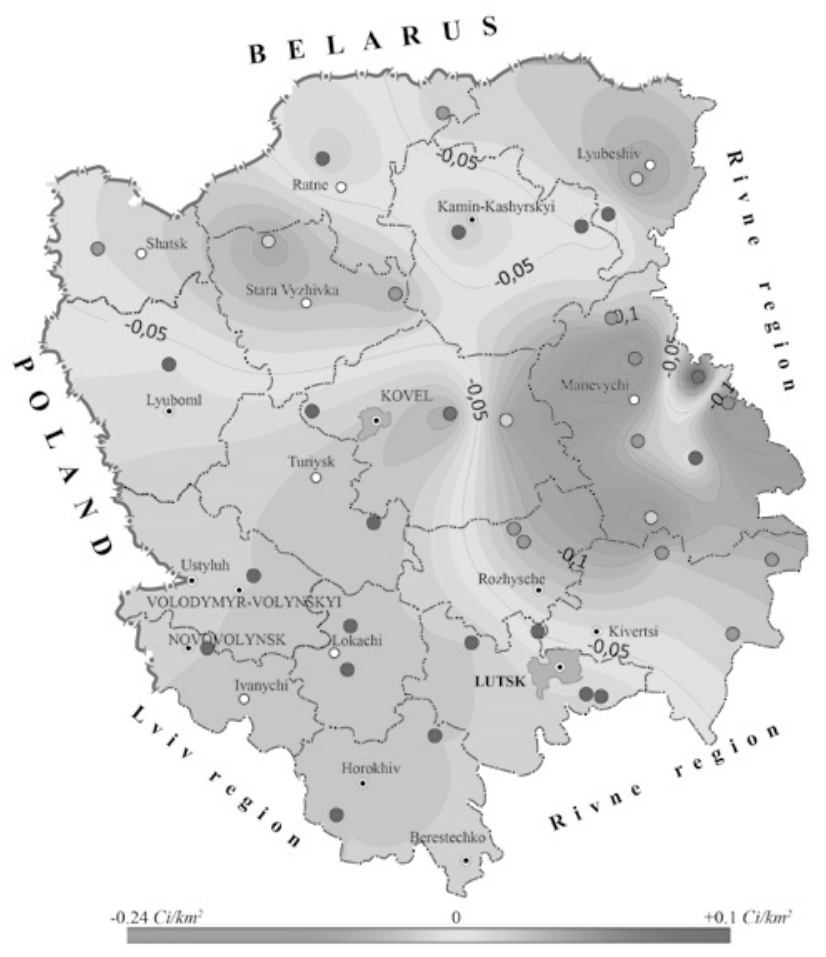

Figure 2. Dynamics of changes of ${ }^{137} \mathrm{Cs}$ content in soils in the surveyed areas of Volyn region, Ukraine (2011-2018) 
Table 4. Contamination of ${ }^{137} \mathrm{Cs}$ in soils on the surveyed areas of the Volyn region, Ukraine (2011-2018)

\begin{tabular}{|c|c|c|c|c|c|c|c|c|c|c|}
\hline \multirow{2}{*}{ No } & \multirow{2}{*}{ Districts } & \multirow{2}{*}{ Settlement } & 2011 & 2012 & 2013 & 2014 & 2015 & 2016 & 2017 & 2018 \\
\hline & & & \multicolumn{8}{|c|}{${ }^{137} \mathrm{Cs}, \mathrm{Ci} / \mathrm{km}^{2}$} \\
\hline 1 & Volodymyr-Volynskyi & Ovadne & 0.03 & 0.03 & 0.02 & 0.02 & 0.02 & 0.02 & 0.01 & 0.01 \\
\hline 2 & Gorokhivsky & Zhuravnyky & 0.03 & 0.04 & 0.02 & 0.02 & 0.02 & 0.01 & 0.01 & 0.01 \\
\hline 3 & Gorokhivsky & Uhryniv & 0.03 & 0.03 & 0.01 & 0.01 & 0.01 & 0.01 & 0.01 & 0.01 \\
\hline 4 & Lutsk (Rokyni Res. Farm) & Rokyni & 0.06 & 0.06 & 0.04 & 0.03 & 0.02 & 0.01 & 0.01 & 0.01 \\
\hline 5 & Ivanychivsky & Hryady & 0.03 & 0.03 & 0.02 & 0.01 & 0.01 & 0.01 & 0.02 & 0.01 \\
\hline 6 & Kamin-Kashirsky & Olenine & 0.12 & 0.15 & 0.09 & 0.12 & 0.09 & 0.07 & 0.05 & 0.07 \\
\hline 7 & Kamin-Kashirsky & Rakiv Lis & 0.07 & 0.07 & 0.08 & 0.08 & 0.06 & 0.05 & 0.04 & 0.05 \\
\hline 8 & Kivertsivsky & Hremyache & 0.12 & 0.11 & 0.08 & 0.04 & 0.02 & 0.02 & 0.02 & 0.03 \\
\hline 9 & Kivertsivsky & Omelne & 0.11 & 0.12 & 0.09 & 0.04 & 0.03 & 0.03 & 0.04 & 0.03 \\
\hline 10 & Kovelsky & Kozlynychi & 0.17 & 0.18 & 0.15 & 0.12 & 0.08 & 0.07 & 0.06 & 0.05 \\
\hline 11 & Kovelsky & Stari Koshary & 0.05 & 0.05 & 0.03 & 0.01 & 0.03 & 0.03 & 0.02 & 0.02 \\
\hline 12 & Kovelsky & Ukhovetsk & 0.08 & 0.09 & 0.10 & 0.11 & 0.07 & 0.07 & 0.08 & 0.09 \\
\hline 13 & Lokachinsky & Hubyn & 0.03 & 0.04 & 0.03 & 0.02 & 0.02 & 0.01 & 0.01 & 0.01 \\
\hline 14 & Lokachinsky & Pryvitne & 0.02 & 0.03 & 0.02 & 0.02 & 0.03 & 0.02 & 0.01 & 0.01 \\
\hline 15 & Lutsk & Vesele & 0.03 & 0.04 & 0.02 & 0.02 & 0.02 & 0.02 & 0.01 & 0.01 \\
\hline 16 & Lutsk & Pidhaytsi & 0.04 & 0.04 & 0.02 & 0.02 & 0.03 & 0.02 & 0.01 & 0.01 \\
\hline 17 & Lutsk & Krupa & 0.04 & 0.05 & 0.02 & 0.02 & 0.02 & 0.01 & 0.01 & 0.01 \\
\hline 18 & Lyubeshivsky & Velyka Hlusha & 0.18 & 0.18 & 0.19 & 0.18 & 0.14 & 0.14 & 0.12 & 0.11 \\
\hline 19 & Lyubeshivsky & Volya Lyubeshivska & 0.24 & 0.24 & 0.21 & 0.19 & 0.17 & 0.15 & 0.13 & 0.12 \\
\hline 20 & Lyubeshivsky & Sedlyshche & 0.22 & 0.23 & 0.18 & 0.18 & 0.16 & 0.16 & 0.17 & 0.18 \\
\hline 21 & Lubomlsky & Kusnyshche & 0.05 & 0.06 & 0.03 & 0.02 & 0.03 & 0.02 & 0.02 & 0.01 \\
\hline 22 & Manevychi & Komarovo & 0.13 & 0.16 & 0.11 & 0.09 & 0.06 & 0.04 & 0.05 & 0.08 \\
\hline 23 & Manevychi & Kostyukhnivka & 0.14 & 0.39 & 0.35 & 0.28 & 0.27 & 0.24 & 0.22 & 0.24 \\
\hline 24 & Manevychi & Lyshnivka & 0.39 & 0.43 & 0.36 & 0.37 & 0.36 & 0.35 & 0.32 & 0.31 \\
\hline 25 & Manevychi & Prylisne & 0.51 & 0.52 & 0.48 & 0.36 & 0.32 & 0.29 & 0.22 & 0.27 \\
\hline 26 & Manevychi & Sytnytsya & 0.27 & 0.02 & 0.12 & 0.13 & 0.11 & 0.10 & 0.11 & 0.09 \\
\hline 27 & Manevychi & Tsminy & 0.25 & 0.30 & 0.20 & 0.18 & 0.11 & 0.01 & 0.03 & 0.03 \\
\hline 28 & Manevychi & Yablun'ka & 0.23 & 0.24 & 0.19 & 0.15 & 0.12 & 0.13 & 0.11 & 0.15 \\
\hline 29 & Ratnivsky & Hirnyky & 0.04 & 0.04 & 0.03 & 0.02 & 0.02 & 0.02 & 0.02 & 0.02 \\
\hline 30 & Rozhyschensky & Pozharky & 0.10 & 0.11 & 0.06 & 0.03 & 0.01 & 0.01 & 0.01 & 0.01 \\
\hline 31 & Rozhyschensky & Perespa & 0.10 & 0.13 & 0.04 & 0.03 & 0.03 & 0.02 & 0.02 & 0.01 \\
\hline 32 & Starovyzhivsky & Krymne & 0.12 & 0.08 & 0.06 & 0.04 & 0.03 & 0.02 & 0.01 & 0.01 \\
\hline 33 & Starovyzhivsky & Synove & 0.10 & 0.11 & 0.07 & 0.04 & 0.03 & 0.02 & 0.02 & 0.01 \\
\hline 34 & Turian & Kupychiv & 0.03 & 0.04 & 0.02 & 0.01 & 0.01 & 0.01 & 0.02 & 0.02 \\
\hline 35 & Kivertsivsky & Tsuman forestry & 0.16 & 0.19 & 0.12 & 0.11 & 0.08 & 0.08 & 0.07 & 0.09 \\
\hline 36 & Shatsky & Pulmo & 0.07 & 0.07 & 0.05 & 0.02 & 0.03 & 0.02 & 0.01 & 0.01 \\
\hline
\end{tabular}

\section{CONCLUSIONS}

The radiological situation in the Volyn region of Ukraine remains stable. There are slight fluctuations of ${ }^{137} \mathrm{Cs}$ and ${ }^{90} \mathrm{Sr}$, which is due to changes in weather conditions, which leads to an increase or decrease in groundwater and as a consequence - the migration of radionuclides.

In order to preserve the natural resource potential of the radioactive contamination zone of the region, it is necessary to carry out a set of agrotechnical and agrochemical measures aimed at reducing radioactive contamination. The main measures include the method of tillage, crop placement and liming of acid soils. Application of organic, mineral fertilizers and sorbents with obligatory liming of acid soils is one of the main ways that can most effectively affect the blocking of radionuclides by the soil absorption complex.

Elucidation of the features of spatial differentiation of radionuclides, establishment of levels of contamination with radioactive elements ${ }^{137} \mathrm{Cs}$, ${ }^{90} \mathrm{Sr}$ soils of the studied area requires further study of 
their migration and accumulation. The problem of radionuclidecontamination has serious socio-economic consequences. The territory needs a long process of socio-economic rehabilitation, which involves the restoration of lost natural resource potential and safe living conditions and the introduction of advanced technologies for the production of environmentally friendly agricultural products.

\section{Conflict of interest}

None declared.

\section{REFERENCES}

1. Dutov O.I., 2014, Ahroekolohichni pidkhody do minimizatsiyi doz oprominennya naselennya u viddalenyy period rozvytku radiolohichnoyi sytuatsiyi pislya avariyi na CHAES [Agroecological approaches to minimizing the radiation doses of the population in the remote period of development of the radiological situation after the Chernobyl accident]. Ekolohichni nauky: naukovopraktychnyy zhurnal. 2014; No 1 (5):24-30 [in Ukrainian].

2. Grunty Volyns'koyi oblasti, 1999 [Soils of Volyn region] / M. Y. Shevchuk, P. Y. Zinchuk, L. K. Koloshko [ta in.]. RVV "Vezha" Volyn. nats. un-tu im. Lesi Ukrayinky, Luts'k: 1999;162 [in Ukrainian].

3. Grygus I., Zukow W., Kushniruk Y., Korotun S.: Medicalgeographical and radiological aspects of the system "environment-population health". Ecological Questions. Vol. 30, No 3, 1-15. http://doi.org/10.12775/EQ.2019.019 [in English].

4. Hromyk O.M.: Radioaktyvne zabrudnennya gruntiv Volyns'koyi oblasti [Radioactive contamination of soils of Volyn region]. Heohrafiya ta turyzm. Vyp. 2011;12:202207 [in Ukrainian].

5. Hromyk O.M., Ilyina O.V.: Radionuklidy ta vazhki metaly $\mathrm{v}$ gruntakh i vodakh terytoriyi radioaktyvnoho zabrudnennya Volyns'koyi oblasti [Radionuclides and heavy metals in soils and waters of the territory of radioactive contamination of Volyn region]. Naukovyy visnyk Skhidnoyevropeys'koho natsional'noho universytetu imeni Lesi Ukrayinky. Heohrafichni nauky. 2016; No 15 (340): 30-39 [in Ukrainian]

6. Hromyk O.M., Ilyina O.V:: 2017, Radionuclides and heavy metals in soils and waters on the territory of radioactive contamination in Volyn region. Science and Education a New Dimension. Natural and Technical Sciences. 2017, Vol. 14, Issue 132, 17-19 [in English].

7. Hromyk O.M., Ilyin L.V. Radioecological analysis of landscapes in Volyn Region: monograph. Lutsk NTU Printing and Publications Center, Lutsk 2020:268 [in English].

8. Ilyin L.V.: Geochemical peculiarities of bottom sediments in polytypic lakes of Ukrainian Polissya. Limnological review. 2002; № 2. 155-163 [in English].

9. Ilyin L.V.: Limnokompleksy Ukrayins'koho Polissya [Limnocomplexes of Ukrainian Polissya]. U 2-kh t. T. 2:
Rehional'ni osoblyvosti ta optymizatsiya. Red.-vyd. vidd. «Vezha» Volyn. nats. un-tu im. Lesi Ukrayinky, Luts'k: 2008;400 [in Ukrainian].

10.Ilyin L.V., Hromyk O.M.: Umist radionuklidiv u limnosystemakh Zakhidnoho Polissya (na prykladi vodoym zony radioaktyvnoho zabrudnennya Volyns'koyi oblasti. [The content of radionuclides in the limnosystems of Western Polissya (on the example of reservoirs of the radioactive contamination zone of Volyn region)]. Naukovyy visnyk Volyns'koho natsional'noho Universytetu imeni Lesi Ukrayinky. Heohrafichni nauky. 2012, No 18 (243), 4-10 [in Ukrainian].

11. Ilyin L.V., Hromyk O.M., Ilyina O.V., Zinchuk M.I.: Radioekolohichnyy analiz zony zabrudnennya Volyns'koyi oblasti Ukrayiny [Radioecological analysis of the pollution zone of Volyn region of Ukraine]. Yaderna ta radiatsiyna bezpeka. 2020, No 1(85):73-80. https://doi. org/10.32918/nrs.2020.1(85).08 [in Ukrainian].

12.Korotun S.I.: Sistema ekologicheskogo monitoringa "Polesye" v Rovenskoy oblasti [Environmental Monitoring System "Polesie" in the Rivne Region]. Vodnyye ekosistemy Kolkhidskoy nizmennosti - okhrana i ratsionalnoye ispolzovaniye. Sbornik trudov Mezhdunar. konf. TGU, Tbilisi: 2013;150-155 [in Russian].

13. Natsionalna dopovid' Ukrayiny. " 25 rokiv Chornobylskoyi katastrofy. Bezpeka maybutn'oho" [National Report of Ukraine " 25 years of the Chornobyl catastrophe. Security of the future"]. KIM, Kyiv: 2011;395 [in Ukrainian].

14. Normy radiatsiynoyi bezpeky Ukrayiny (NRBU-97) [Radiation safety standards of Ukraine (NRBU-97)] // Derzhavni hihiyenichni normatyvy. VP UTSD MOZ Ukrayiny, Kyiv: 1997;121 [in Ukrainian].

15. Romanchuk L.D.: Radioekolohichna otsinka formuvannya dozovoho navantazhennya u meshkantsiv sil's'kykh terytoriy Polissya Ukrayiny [Radioecological assessment of dose formation in residents of rural areas of Polissya, Ukraine]. Polissya, Zhytomyr: 2015;300 [in Ukrainian].

16. Samoylenko V.M: $\quad$ Kompleksne rayonuvannya radioaktyvno zabrudnenykh terytoriy Polissya i pivnochi Lisostepu za hidrolohichno-landshaftnymy umovamy ta mozhlyvymy radioekolohichnymy naslidkamy mistsevoho vodo- i resursokorystuvannya [Complex zoning of radioactively contaminated territories of Polissya and the north of the Forest-Steppe according to hydrological and landscape conditions and possible radioecological consequences of local water and resource use]. Nika-Tsentr, Kyiv: 1999;280 [in Ukrainian].

17. Tavrov Yu.S.: Minlyvist' rozpodilu i spivvidnoshennya radioaktyvnoyi zabrudnenosti mizh lankamy ekosystem Polissya ta pivnochi Lisostepu [Variability of distribution and ratio of radioactive contamination between the links of ecosystems of Polissya and the north of the Forest-Steppe]. Hidrolohiya, hidrokhimiya i hidroekolohiya. 2001; Vol. 2:689-695 [in Ukrainian].

Received: 10.07 .2020

Accepted: 23.10 .2020

This article is available in Open Access model and licensed under a Creative Commons Attribution-Non Commercial 3.0.Poland License (CC-BY-NC) available at: http://creativecommons.org/licenses/by-nc/3.0/pl/deed.en 